University of Nebraska - Lincoln

DigitalCommons@University of Nebraska - Lincoln

USDA National Wildlife Research Center - Staff Publications
U.S. Department of Agriculture: Animal and Plant Health Inspection Service

July 2001

\title{
SURGICAL STERILIZATION AS A METHOD OF REDUCING COYOTE PREDATION ON DOMESTIC SHEEP
}

\author{
Cassity Bromley \\ Utah State University, Logan, UT \\ Eric M. Gese \\ Utah State University, eric.gese@usu.edu
}

Follow this and additional works at: https://digitalcommons.unl.edu/icwdm_usdanwrc

Part of the Environmental Sciences Commons

Bromley, Cassity and Gese, Eric M., "SURGICAL STERILIZATION AS A METHOD OF REDUCING COYOTE PREDATION ON DOMESTIC SHEEP" (2001). USDA National Wildlife Research Center - Staff Publications. 594.

https://digitalcommons.unl.edu/icwdm_usdanwrc/594

This Article is brought to you for free and open access by the U.S. Department of Agriculture: Animal and Plant Health Inspection Service at DigitalCommons@University of Nebraska - Lincoln. It has been accepted for inclusion in USDA National Wildlife Research Center - Staff Publications by an authorized administrator of DigitalCommons@University of Nebraska - Lincoln. 


\title{
SURGICAL STERILIZATION AS A METHOD OF REDUCING COYOTE PREDATION ON DOMESTIC SHEEP
}

CASSITY BROMLEY, ${ }^{1}$ Department of Fisheries and Wildlife, Utah State University, Logan, UT 84322-5210, USA

ERIC M. GESE, 2 National Wildlife Research Center, Department of Fisheries and Wildlife, Utah State University, Logan, UT 84322-5295, USA

\begin{abstract}
Predation by coyotes (Canis latrans) on domestic sheep is a problem for many livestock producers throughout the United States Intermountain West. We examined whether surgical sterilization of coyote packs would modify their predatory behavior and reduce predation rates on domestic sheep as compared to coyote packs with pups. From June 1997 to December 1997, we gathered baseline information on coyote pack size and movements. In winter 1998, we surgically sterilized and radiocollared members of 5 coyote packs. We also captured and radiocollared members of 6 packs that remained intact (i.e., reproductive). During summer 1998, only 1 sterile pack killed a lamb, while 3 intact packs killed 11 lambs. When only sheep-killing packs were included, sterile packs killed an average of 0.35 lambs/week, while intact packs killed 1.53 lambs/week in 1998. During winter 1999, we monitored 4 sterile and 8 intact packs. In summer 1999, 3 sterile packs killed 3 lambs, while 4 intact packs killed 22 lambs. Considering only sheep-killing packs, sterile packs killed on average 0.38 lambs/week, while intact packs killed an average of 2.95 lambs/week in 1999. Coyotes were more likely to kill lambs that were on the edges of coyote territories as compared to core areas. Lambs of less than average weight were also more likely to be killed by coyotes. The available rodent biomass in each territory was not an influence on the differential kill rates exhibited between sterile and intact packs, nor did the amount of available alternate prey influence annual coyote predation rates on sheep. We conclude that we could use surgical sterilization to modify the predatory behavior of coyotes associated with pup production and provisioning of pups. Sterilization successfully reduced, but did not eliminate, coyote predation on domestic sheep. The amount of losses averted in the first year exceeded the costs associated with surgically sterilizing a coyote pack, which indicates that surgical sterilization could prove beneficial on small-scale livestock operations.
\end{abstract}

JOURNAL OF WILDLIFE MANAGEMENT 65(3):510-519

Key words: Canis latrans, coyote, domestic sheep, predation, sterilization, survival.

Coyotes are a major predator of domestic sheep and lambs throughout the western United States. Pearson (1986) reported that $2.5 \%$ of adult sheep and $9.0 \%$ of lambs were lost to predators annually; coyotes were the major predator accounting for $74 \%$ and $78 \%$ of adult sheep and lamb losses, respectively. In 1994, predators accounted for the loss of 520,600 sheep and lambs, and coyotes caused $62 \%$ of those losses (Simpson 1995). Utah ranchers reported the loss of 19,000 sheep and lambs to coyotes in 1997 (31.3\% of total losses; U.S. Department of Agriculture 1998). Sheep producers have cited high predation losses, low lamb and wool prices, and a shortage of good hired labor as reasons for leaving the sheep industry (Gee et al. 1977).

Traditionally, lethal nonspecific methods have been used to reduce or stop coyote predation, assuming that fewer coyotes means fewer livestock losses. Recent research in California suggests that

\footnotetext{
1 Present address: U.S. National Park Service, Santa Monica Mountains National Recreation Area, 401 West Hillcrest Drive, Thousand Oaks, CA 91360, USA.

2 E-mail: egese@cc.usu.edu
}

breeding pairs of coyotes are responsible for most of the killing (Sacks et al. 1999) and that targeting breeding individuals may be a more effective control method. In addition, attitudes toward lethal control have changed (Andelt 1996, Reiter et al. 1999), and a variety of nonlethal control methods are now available or in practice. Currently, nonlethal control methods include various livestock husbandry practices, fencing, guard animals (dogs, llamas, and other aggressive livestock), and frightening devices (Andelt 1987, Knowlton et al. 1999). Aversive conditioning, repellents, and antifertility agents have been explored as a means to reduce coyote populations and/or livestock losses (Balser 1964, Bourne and Dorrance 1982, Lehner 1987). However, costs of labor and materials, maintenance, and lack of success in open range situations have limited the use of many nonlethal control techniques and made those techniques difficult to promote among sheep producers (Knowlton et al. 1999).

The use of fertility control as a nonlethal method to manage wildlife populations has prompted increasing interest in recent years 
(Garrott 1995). Most efforts have focused on developing and testing various contraceptive substances (Elder 1964, Stellfug et al. 1978, Millar et al. 1989) or methods of drug administration (Matschke 1977, Plotka and Seal 1989, Kirkpatrick et al. 1990). Computer models that illustrate the potential of canid fertility control have been developed (Haight and Mech 1997, Pech et al. 1997). Research designed to evaluate the potential of canid fertility control has documented changes in reproduction (Balser 1964) as well as behavioral responses to sterilization (Mech et al. 1996, Saunders and Mcllroy 1996, Bubela 1999). However, no studies have addressed the effect of sterilization on depredation behavior.

Till and Knowlton (1983) showed that predation on domestic lambs by adult coyotes stopped when their pups were removed. They theorized that sterilizing territorial coyotes could be more effective than removing the pups of depredating adults because (1) no lamb loss would occur before the pups were removed; (2) the sterilized coyotes may keep out other reproductive coyotes that might cause sheep losses; and (3) sterilization may reduce losses for many years because pair bonds between coyotes are long-lasting. Implicit in this theory are the untested assumptions that (1) sterilized resident (or dominant) coyotes maintain their territories to the exclusion of nonsterilized coyotes; (2) sterilization has the same effects as pup removal; and (3) compensatory mechanisms within the population do not counteract the effects of sterilization. We did not attempt to control the size of the coyote population, but only modify predatory behavior. We hypothesized that sterile coyotes, without the energetic demands of provisioning pups, would kill fewer sheep than coyotes with pups. Because other factors may also influence depredation rates (Knowlton et al. 1999), we examined the timing and location of depredation events, the weight of lambs killed by coyotes, the availability of alternate prey, and food availability (as measured by a rodent biomass index) in coyote territories exhibiting differential kill rates.

\section{STUDY AREA}

We conducted the project on a $400-\mathrm{km}^{2}$ study area on the Deseret Land and Livestock ranch, northeastern Utah. The study area is primarily sagebrush (Artimesia tridentata wyomingensis) steppe, with an understory of western wheatgrass (Pascopyrum smithii), needle-and-thread grass (Stipa comata), Indian rice grass (Oryzopsis hymenoides), and planted crested wheatgrass
(Agropyrum desertorum). Average annual rainfall is $27.6 \mathrm{~cm}$; temperatures range from an average of $-9.4^{\circ} \mathrm{C}$ in winter to $15.6^{\circ} \mathrm{C}$ in summer.

Coyotes were distributed throughout the study area and were relatively unexploited. While sheep grazing was a historical use of the area, sheep had not grazed the study area recently. Cattle were grazed intermittently throughout the area. Winter carrion in the form of cattle and elk (Cerous elaphus) carcasses was plentiful. Mule deer (Odocoileus hemionus) and pronghorn antelope (Antilocapra americana) were common in the area. The most abundant small prey were white-tailed jackrabbits (Lepus townsendii), cottontail rabbits (Sylvilagus nutalli), Uinta ground squirrels (Spermophilus armatus), deer mice (Peromyscus maniculatus), and least chipmunks (Tamias minimus).

\section{METHODS}

During summer 1997, coyotes were trapped with \#3 padded-jaw, leg-hold traps equipped with tranquilizer tabs (Balser 1965, Sahr and Knowlton 2000) containing propriopromazine. Captured coyotes were immobilized with ketamine hydrochloride $(10 \mathrm{mg} / \mathrm{kg})$ and acepromozine $(0.1 \mathrm{mg} / \mathrm{kg})$. Coyotes were weighed, sexed, blood sampled, and aged by tooth wear (Gier 1968). A premolar was extracted and sent to a commercial lab (Matson's Laboratory, Milltown, Montana, USA) for aging by cementum annuli analysis (Linhart and Knowlton 1967). Animals were radiocollared with a 150-g transmitter (Advanced Telemetry Systems, Isanti, Minnesota, USA) and released at the point of capture.

During December 1997, January 1998, and January 1999, a hand-held net-gun fired from a helicopter was used to capture coyotes (Barrett et al. 1982, Gese et al. 1987). Previously radiocollared animals were recaptured along with as many pack members as possible. Additional packs in the study area were also captured. Packs were randomly assigned to sterile and sham treatments. Because identification of alpha breeding coyotes is difficult without field observation, members of the same pack received the same treatment. Captured coyotes were transported by helicopter to a local veterinary clinic for surgical sterilization. Females were sterilized by tubal ligation and males by vasectomy, leaving hormonal systems intact (Zemlicka 1995). Animals in the sham treatment underwent all procedures except actual sterilization. All animals were held overnight for recovery and observation, then released at the point of capture the following morning. 
During 1997 and 1998, coyotes were relocated primarily from fixed stations (null-peak) positioned around the perimeter of the study area (White and Garrott 1990). In 1999, we used hand-held triangulation to acquire bearings $<10$ min apart with triangulation angles between $20^{\circ}$ and $160^{\circ}$ (Gese et al. 1990). The software package LOCATE (Pacer, Truro, Nova Scotia) was used to calculate animal locations. We attempted to locate all coyotes twice daily (morning and evening) during the time sheep were in the study area (May through Sep). During the remainder of the year, coyotes were located approximately every 2 weeks using aerial telemetry (Mech 1983) when snow made roads impassable for ground relocations. Home ranges were calculated using CALHOME (Kie et al. 1996). The adaptive kernel estimator (Worton 1989) was used to delineate territory boundaries ( $90 \%$ isopleth) and core areas (60\% isopleth) of use. To confirm breeding status of the pack, searches were made by foot and in the air of all coyote territories to find dens and confirm the presence or absence of pups. Responses to simulated howling were also used to determine the presence of pups during summer (Harrington and Mech 1982).

To assess coyote predation rates on sheep, small bands of ewes and lambs were introduced into the study area. Because we herded and monitored the bands daily, we had the ability to systematically move the sheep through all the coyote territories in the study area. In 1997, we released 222 ewes and 195 lambs on the ranch in mid-June; 10 ewes were radiocollared to assist in flock location. This flock served to expose all the coyotes in the area to sheep prior to any treatment. In 1998, we released 138 ewes and 173 lambs on the study area in early June; we radiocollared 50 lambs (29\% of the lambs) to aid in finding kills. In 1999, we started in mid-May with 136 ewes and 150 lambs transported to the study site. Because finding all the kills in 1998 proved difficult, all lambs $(n=150)$ in 1999 were radiocollared. In both 1998 and 1999, the sheep were split into 2 flocks to maximize coyote exposure to sheep. All flocks were removed from the ranch in mid-September of each year. Most lambs were about 3 weeks old at the time of release.

Because lamb age affects vulnerability to coyote predation (Andelt 1987, Knowlton et al. 1999), we moved the flocks so that each coyote pack was exposed to 1 flock early in the season and the other flock later in the season. Approximately once a month, the sheep were penned, lambs weighed, and the radiocollars adjusted as necessary. The sheep were relocated each day, and whenever possible the bed site area was searched for kills. Radiocollared lambs with mortality signals were located as soon as possible. Death sites were searched for tracks, scat, and other sign of predator presence. Dead lambs were necropsied, and hemorrhaging, bite marks, and other evidence at the kill site was used to determine the cause of death (Rowley 1970, Wade and Bowns 1985). Kills located in a specific coyote pack territory were attributed to that pack unless evidence from telemetry suggested otherwise.

Because the number of days sheep were in coyote territories varied, the kill rate of sheep in each coyote territory was standardized to a 1-week interval. A Students $t$-test was used to compare weekly kill rates of sterile and intact packs. To account for both flock size and length of time spent in each territory (i.e., exposure days), a weekly survival rate for the sheep grazed within each coyote territory was also calculated (Heisey and Fuller 1985). Sheep survival rates were only calculated for 1999 when all lambs were radiocollared. A $t$-test was used to compare the weekly sheep survival rates between intact and sterile coyote packs. Because coyote pack size could influence depredation rates, we performed a regression analysis of the number of coyotes in a pack versus the number of lambs killed by that pack.

Small mammal-trapping grids and spotlight surveys were used to determine numbers and types of alternative prey available on the study area. Spotlighting transects (Smith and Nydegger 1985) were conducted from a vehicle traveling at 10-15 km/hr after dark in mid-June and late August. White-tailed jackrabbits and cottontail rabbits were counted, and the number of lagomorphs observed $/ \mathrm{km}$ was compared to an existing data set for the study area (Rick Danvir, Deseret Land and Livestock Co., unpublished data). Small mammal-trapping grids were located across 4 habitat types (meadow, sparse vegetation, moderately dense sagebrush, and dense sagebrush). Two $30.5 \times 91.4 \mathrm{~m}$ grids of $96 \mathrm{Sher}-$ man live traps were established in each habitat type and run for 3 consecutive nights. Traps were checked each morning; animals were identified, marked, and released. The average weight of each small mammal species was multiplied by the number of small mammals captured per 100 operable trap-nights to calculate a rodent biomass index for each habitat type. After we determined the amount of each habitat type in each 
coyote territory, an index of available rodent biomass was then calculated for each territory by multiplying the amount of each habitat type in the territory by the biomass index for that habitat type. A $t$-test was then used to compare the indices of available rodent biomass between intact and sterile coyote packs. Home range size and habitat analyses were preformed for packs with $\geq 1$ radiocollared coyote.

\section{RESULTS}

\section{Capture and Surgical Treatments}

Data were collected from June 1997 to September 1999, with the most intense data collection occurring during the summer when sheep were present (May-Sep). We captured 11 coyotes $(7 \mathrm{M}$, $4 \mathrm{~F}$ ) in 1997. Two sessions of aerial net-gunning during winters 1998 and 1999 resulted in the capture of an additional $31(22 \mathrm{M}, 9 \mathrm{~F})$ coyotes, plus the recapture of 10 of 11 coyotes trapped in 1997. Ten males and 9 females were given sham operations, while 20 males and 6 females were sterilized. No capture or surgery-related mortalities were observed. If the alpha pair was not sterilized and pups were observed, the pack was classified as an intact pack. In 4 packs, no members were captured or radiocollared, but pack members were observed and the home range boundary was estimated based on the spatial arrangement of adjacent radiocollared packs (Fritts and Mech 1981, Messier 1985, Fuller 1989).

\section{Coyote Kill Rates}

In 1998, we monitored 5 sterile and 6 intact packs (Table 1). Sheep spent an average of 16.5 days in each coyote territory. The 5 sterile packs were responsible for $1 \mathrm{kill}$, and the average number of kills per week by all sterile packs was $0.07( \pm 0.16$ $\mathrm{SD})$. The 6 intact packs killed 11 lambs, for a weekly average of $0.77 \pm 0.92(t=1.63, \mathrm{df}=9, P=$ 0.068 ). The observed frequency of kills between the 2 treatments (sterile vs. intact) was different than expected $\left(\chi^{2}=6.656, \mathrm{df}=1, P=0.0099\right)$, with intact packs killing more lambs (11 kills observed, 6.55 expected) and sterile packs killing fewer lambs ( 1 kill observed, 5.45 expected) than expected. A regression analysis of coyote pack size versus

Table 1. Predation rates and pack sizes of sterile and intact coyote packs during 1998 and 1999, Deseret Land and Livestock, Utah. Pack counts do not include young-of-year and reflect pre-whelping pack size.

\begin{tabular}{|c|c|c|c|c|c|c|c|}
\hline Year & Pack & Treatment & $\begin{array}{l}\text { Minimum } \\
\text { pack size }\end{array}$ & \# of kills & $\begin{array}{c}\text { Days sheep } \\
\text { present }\end{array}$ & Kills/week & $\begin{array}{l}\text { Lamb survival } \\
\text { rate (weekly) }\end{array}$ \\
\hline \multirow[t]{11}{*}{1998} & Stacy & Sterile & 3 & 0 & 18 & 0 & - \\
\hline & South Cabin & Sterile & 3 & 0 & 20 & 0 & - \\
\hline & Crane & Sterile & 4 & 1 & 20 & 0.35 & - \\
\hline & Highway & Sterile & 2 & 0 & 12 & 0 & - \\
\hline & Alkali & Sterile & 2 & 0 & 20 & 0 & - \\
\hline & Red Hill & Intact & 3 & 2 & 16 & 0.88 & - \\
\hline & Dry Creek & Intact & 6 & 0 & 13 & 0 & - \\
\hline & Road Hollow & Intact & 2 & 0 & 14 & 0 & - \\
\hline & Shortcut & Intact & 2 & 4 & 17 & 1.65 & - \\
\hline & North Cabin & Intact & 3 & 5 & 17 & 2.06 & - \\
\hline & McKay & Intact & 2 & 0 & 15 & 0 & - \\
\hline \multirow[t]{12}{*}{1999} & Stacy & Sterile & 2 & 1 & 23 & 0.30 & 0.997 \\
\hline & Red Hill & Sterile & 3 & 1 & 16 & 0.44 & 0.997 \\
\hline & Murphy & Sterile & 2 & 1 & 17 & 0.41 & 0.997 \\
\hline & South Cabin & Sterile & 2 & 0 & 16 & 0 & 1.00 \\
\hline & Table & Intact & 3 & 0 & 15 & 0 & 1.00 \\
\hline & Crane & Intact & 4 & 13 & 18 & 5.06 & 0.963 \\
\hline & Dry Creek & Intact & 5 & 1 & 19 & 0.37 & 0.997 \\
\hline & Road Hollow & Intact & 2 & 0 & 19 & 0 & 1.00 \\
\hline & Munshaw & Intact & 3 & 0 & 16 & 0 & 1.00 \\
\hline & Lake Hollow & Intact & 2 & 0 & 20 & 0 & 1.00 \\
\hline & Shortcut & Intact & 2 & 3 & 5 & 4.20 & 0.996 \\
\hline & North Cabin & Intact & 6 & 5 & 16 & 2.19 & 0.985 \\
\hline
\end{tabular}


the weekly kill rate on sheep revealed no significant relationship $\left(r^{2}=0.008, F=0.078, P=0.786\right)$.

Of the 11 coyote packs monitored in 1998,4 sterile and 3 intact packs did not kill sheep. When only the sheep-killing coyote packs were considered, the sterile pack killed 0.35 lambs/week. The 3 intact packs killed an average of 1.53 lambs/week. Thus, among coyote packs that killed sheep, there were 4.4 times more lambs killed/week by intact coyote packs than by sterile packs.

In 1999, we monitored 4 sterile and 8 intact packs (Table 1). Sheep spent an average of 16.6 days in each territory. Sterile packs killed 3 lambs, for an average of $0.29 \mathrm{kills} /$ week $( \pm 0.20$ SD), while intact packs killed 22 sheep, for an average of 1.48 kills/week $( \pm 2.09 ; t=1.167, \mathrm{df}=$ $10, P=0.147)$. However, intact packs killed more lambs and sterile packs killed fewer lambs than expected $\left(\chi^{2}=5.114\right.$, df $\left.=1, P=0.0237\right)$. There was no relationship between coyote pack size and the weekly kill rate for each pack in $1999\left(r^{2}=\right.$ $0.08, F=0.87, P=0.37$ ).

Of the 12 coyote packs monitored in 1999, 1 sterile pack and 4 intact packs did not kill sheep. Among sheep-killing packs, the average number of sheep killed per week was lower $(0.38 \pm 0.07)$ for sterile packs than for intact packs $(2.95 \pm 2.10$ kills/wk; $t=2.0677$, $\mathrm{df}=5, P=0.0468$ ). Among coyote packs that killed sheep, intact packs were 7.8 times more likely to kill sheep than were sterile packs. Combining both years, intact coyote packs $(\bar{x}=2.34 \pm 1.70 \mathrm{kills} / \mathrm{wk})$ killed 6 times more sheep than sterile packs $(\bar{x}=0.38 \pm 0.06$ kills $/$ wk; $t=2.23, \mathrm{df}=9, P=0.0261$ ).

When sheep survival rates were compared between sham and sterile packs, the weekly survival rate tended to be higher for sheep in sterile coyote territories $(\bar{x}=0.998)$ than in intact coyote territories $(\bar{x}=0.989)$. Among sheep-killing packs, the weekly sheep survival rate was higher in sterile coyote packs $(\bar{x}=0.997 \pm 0.00)$ than in intact packs $(\bar{x}=0.985 \pm 0.016 ; t=2.01, \mathrm{df}=5, P=0.05)$.

\section{Characteristics of Kills}

During 1999, coyotes killed 25 lambs. Seven additional lambs died of causes not related to coyote predation: drowning (1), pneumonia (2), and unknown causes (4). Coyotes completely consumed 13 of the sheep killed, partially consumed 6 kills, and left 3 kills intact. No consumption data were available for 3 kills. Coyotes tended to kill lambs from the lightest weight quartile $\left(\chi^{2}=10.15, P<0.01\right)$ more frequently than lambs from the heavier quartiles (Fig. 1),

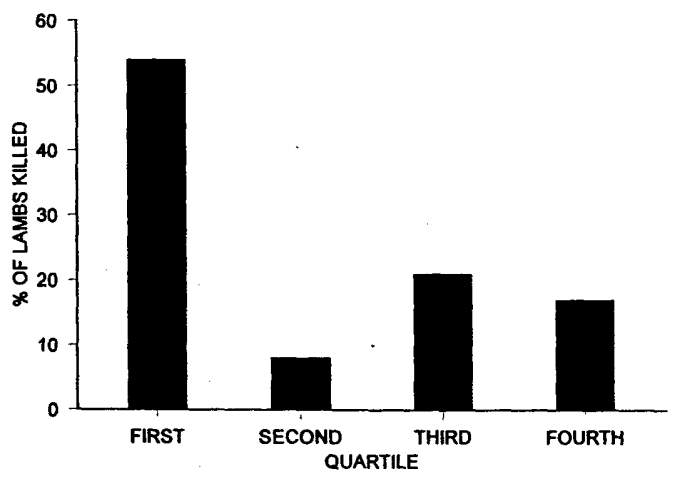

Fig. 1. Percent of sheep killed by coyotes among the 4 quartile weight classes, Deseret Land and Livestock, Utah, 1999. Quartile ranges are: first $(1-25 \%)$, second $(26-50 \%)$, third $(51-75 \%)$, and fourth $(76-100 \%)$.

but they were capable of killing even the heaviest lambs. Lambs were classed into weight quartiles by comparing their last live weight to the rest of the lambs in the herd. Thus, the weight of lambs in the lightest quartile increased over the grazing season, and coyotes were selecting mostly the lightest lambs available. Lambs that strayed or had been located apart from the main flock on the previous day were more likely to be killed than those remaining with the flock.

\section{Location and Timing of Kills}

In 1998, coyotes killed 3 sheep in the core and 4 sheep on the edge of their territories. Based on a comparison of sheep locations and kill locations, the distribution of kills was not different from expected $\left(\chi^{2}=0.234, P=0.62\right)$. In 1999, there was a slight difference $\left(\chi^{2}=3.01, P=0.08\right)$ between the distribution of kills observed in the core $(n=$ 3 ), and on the edge $(n=16)$ of territories, and the expected distribution of kills. This is true even though the analysis accounted for the amount of time sheep spent on the edge and in the core. We found no evidence of coyotes following sheep outside their territory. However, many kills were located in areas of overlap between territories, and 1 kill that was just inside the $60 \%$ isopleth was assigned to the neighboring pack because, based on radiotelemetry locations, the residents were not in that area on the night of the kill.

Kill rates of sheep by coyotes increased over the summer, particularly among intact coyote packs (Fig. 2). Sterile packs that killed sheep did so at a relatively constant rate. The increase in kill rate among intact coyote packs is likely due to the 


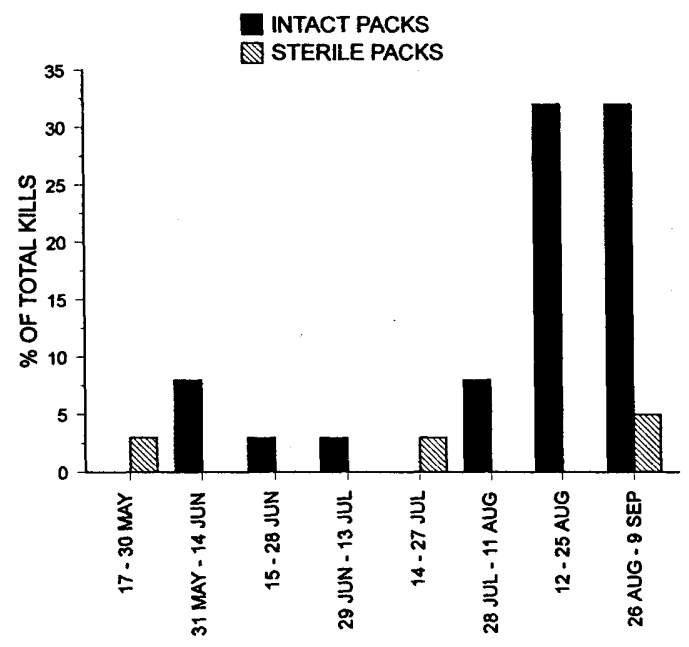

Fig. 2. The timing of lambs killed over the 4-month grazing season by sterile and intact coyote packs, Deseret Land and Livestock, Utah, 1998-1999.

increasing energy demand of growing pups. A reduction in alternate prey (ground squirrels enter hibernation in late Aug) was also considered as a possibility for increased killing, but did not explain the lack of increased killing among the sterile packs.

\section{Influence of Alternative Prey on Predation Rates}

White-tailed jackrabbit numbers were well below their 1991 peak (Rick Danvir, Deseret Land and Livestock Co., unpublished data), but increased during the study. The lagomorph spotlight index increased from 0.29 rabbits $/ \mathrm{km}$ in 1997 to 1.25 rabbits $/ \mathrm{km}$ in 1999 . Small mammal-trapping grids yielded 0 to 0.063 animals/trap night, with no significant difference (all paired comparisons had $P>0.10$ ) in the number of animals captured between any of the years. Increasing lagomorph numbers did not appear to influence coyote predation rates on sheep. The increase in sheep kills from 1998 to 1999 was probably due to our increased ability to find and recover kills because all lambs were radiocollared in 1999.

\section{Influence of Available Rodent Biomass on Predation Rates}

We found no significant difference in the indices of available rodent biomass between sterile coyote packs $(8,766 \pm 1,552)$ and intact packs $(7,930 \pm 1,752 ; t=-0.75, \mathrm{df}=10, P=0.48)$. Thus, differences in kill rates between sterile and intact packs were not in response to differential prey biomass in the territories. Similarly, regression analysis indicated no relationship between the weekly kill rate on sheep and the rodent biomass index in each territory $\left(r^{2}=0.06, F=4.34, P=0.53\right)$.

\section{Costs and Benefits of Sterilization}

We estimated the cost to surgically sterilize a coyote was $\$ 560 /$ animal (helicopter flight time: $\$ 300$, surgery: $\$ 75$, transport: $\$ 60$, fixed-wing flying: $\$ 60$, personnel: $\$ 55$, supplies: $\$ 10$ ). On average we captured and sterilized 3 coyotes/pack; thus, the cost of sterilizing a coyote pack was $\$ 1,680$. Sterile coyote packs killed an average of $0.38 \mathrm{lambs} /$ week, while intact packs killed on average 2.34 lambs/week. Since sterilization did not necessarily stop predation, we used the difference between the 2 treatments as the amount of loss averted (1.96 lambs killed/wk). We used the kill rates of sheep-killing packs only because non-killing packs would require no management action. Using this difference in averted losses, we calculated that over a summer grazing season (16 wks) approximately 32 lambs would not be killed. With a market value of $\$ 56 /$ lamb ( $\$ 0.70$ per pound $\times 80$ pound lamb), we estimated that $\$ 1,792$ of lambs was the amount of losses averted in 1 4-month grazing season. Thus, if a smallscale livestock operation was affected by 1 coyote pack during the summer, then the cost to surgically sterilize them would equal the amount of lambs saved in the first year. Considering the life span of coyotes and length of pair-bonds, surgically sterilizing coyote packs on a small scale could be economically feasible if the sterilized coyotes are allowed to survive (i.e., if the coyotes are killed, then the costs to sterilize begin again).

\section{DISCUSSION}

Animals producing offspring may maximize their hunting efficiency by preying on larger prey (Royama 1970, Harrison and Harrison 1984). In addition, transport costs of delivering a larger prey item to the young may also be more profitable than small-sized prey (Till and Knowlton 1983), at the same time providing for increased energetic requirements of a growing litter. Our data indicate that coyotes change their predatory tendencies when pups are present and that sterilization could be an effective method of reducing coyote predation on domestic sheep in the Intermountain West. None of the sterile coyote packs killed more than 1 lamb per season, while intact 
packs had multiple killing events. Among coyote packs that killed sheep, the rate of predation on sheep was significantly lower for packs that were not provisioning pups.

For this technique to be successful, the breeding pair must be sterilized. In 1999, 1 of the packs that was originally believed to be sterile killed 5 lambs. No pups were seen in the area during initial searches from the air or on foot. However, further investigation showed the breeding pair had not been captured and sterilized, resulting in at least 2 pups being produced. This observation underscores the need to sterilize at least 1 and preferably both members of the breeding pair to prevent pup production.

This study presents further evidence that not all coyotes kill sheep (Sacks et al. 1999). In some areas where pups were present, no lambs were killed by some coyote packs even after 3 years of exposure to sheep. These coyote territories represent situations in which no control measures should be undertaken. The pressure for the adults to provision their pups is only 1 factor driving predation on sheep. Characteristics of individual packs and territories may also be critical in determining which coyotes kill sheep. Further investigation into the sheep-killing tendencies of pups from packs that killed and ate sheep versus pups from packs that seemed to ignore sheep may be useful.

Alternate prey availability may influence coyote predation rates on native prey (Hoffman 1979, Hamlin et al. 1984) and domestic sheep (McAdoo 1975, Guthery 1977, Kauffeld 1977, Gober 1979). Deer fawn (0. virginianus) availability, as regulated by winter severity, affected the rate at which wolves killed livestock in Minnesota (Mech et al. 1988). Hamlin et al. (1984) suggested that coyote predation on deer fawns was lowest during summers when microtine rodent numbers were highest. Our study occurred during years when the abundance of lagomorphs and ground squirrels was fairly typical for the region. We found that indices of available rodent biomass did not affect the number of lambs killed in each territory. Similarly, lagomorph abundance did not appear to influence annual coyote predation rates on sheep. In addition, coyotes had access to antelope and deer fawns, but it was unknown whether coyotes preferred fawns over sheep, or if sterile coyotes killed fewer fawns similarly to killing fewer lambs.

We documented 1 trespass kill, just inside the neighbors' core area (60\% isopleth), but trespass killing seemed to be a rare occurrence. Unlike Shivik et al. (1996), we did not observe an increase in core area overlap between adjacent pack territories when sheep were present, nor did we record coyotes following sheep into neighbors' territory. We did document a higher rate of kills on the edges of territories than expected by chance, so sheep in an area of territory overlap (at the 95\% isopleths) could be accessible to more than 1 pack.

Most of the lambs killed were consumedimplying that they were being used as a food source-though unconsumed kills were located in both sterile and intact coyote territories. We had insufficient data to determine litter size of coyotes, but further research focusing on the relationship between the number of pups and predation rates on lambs should be considered. The timing of kills, with increasing kills by intact packs over the summer and into early fall has been documented (Klebenow and McAdoo 1976, Tigner and Larson 1977, Boggess et al. 1980). This increase in predation likely reflects increased energy demand of growing pups (Oftedal and Gittleman 1989). Reduced alternate prey levels (i.e., ground squirrels going into hibernation) were also considered. However, sterile coyote packs did not increase their predation rate on sheep similarly to the intact packs when ground squirrels entered hibernation in mid-August. Learning and development of hunting behavior of pups (Till and Knowlton 1983) could also be a possibility, but seemed unlikely at that time of year (i.e., the pups would be $\leq 4$ months old in mid-Aug).

Among the large social carnivores, hunting is a cooperative activity that usually involves several group members (e.g., wolves: Mech 1966, 1970; Peterson 1977; Carbyn et al. 1993). However, Thurber and Peterson (1993) observed single wolves capable of killing moose (Alces alces) on Isle Royale. We found that the size of the coyote pack had no effect on the weekly kill rate on lambs. Lambs can be killed by a single coyote (Wade and Bowns 1985), and since most kills on sheep are usually attributed to the breeding pair (Sacks et al. 1999), additional pack members do not seem to increase the rate of depredation on sheep. For native ungulates, cooperative hunting by coyotes may facilitate capture of larger prey, but it is not always necessary (Gese and Grothe 1995).

The coyotes followed in this study did not kill adult sheep. Two ewes were attacked and bitten on the neck, but both survived the attacks. The 
largest lamb killed by coyotes weighed $44 \mathrm{~kg}$ and was larger than some of the ewes in the flock. It may be that coyotes would have killed ewes if exposure was continued, especially if ewes were present without lambs. Our research differs from studies conducted in north-coastal California (Conner et al. 1998, Sacks et al. 1999), because in our study area (and in much of the Intermountain West) lambs were only available seasonally. Adult sheep are available on a year-round basis, and lambs are available over 9 months in northcoastal California (Conner et al. 1998, Sacks et al. 1999). In the Intermountain West, the birth of lambs occurs later than in north-coastal California and generally corresponds with the coyote pup-rearing season. Therefore, sterilization may not have as great an effect in modifying coyote predation behavior in areas where lambs are considered a year-round prey item.

\section{MANAGEMENT IMPLICATIONS}

We designed this experiment to test whether surgical sterilization can change the predatory tendencies of coyotes and whether the procedure will reduce (but not completely stop) predation on domestic lambs. A more efficient method of fertility control would likely be needed for application as a viable management tool on a larger scale. Sterile coyotes maintained territories and pair bonds in a manner similar to non-sterile coyotes (Bromley 2000). In areas where long-term removal has had a limited effect on reducing predation (Conner et al. 1998), a pair of sterile coyotes occupying a territory-that are not killing sheep or killing at very low rates-could serve as an effective deterrent to other coyotes. Our technique of capture and surgical sterilization may be cost-effective. Till (1982) estimated that it costs $\$ 208$ to locate and remove 1 den of pups. Wagner and Conover (1999) estimated that it costs about $\$ 185$ to kill a coyote from a fixed-wing aircraft and about $\$ 805$ to trap a coyote on the ground. However, trapping, denning, and aerial gunning all require annual reapplication of those techniques, while sterilization can be effective for as long as the coyotes survive (or continue as alpha animals). A comparison of costs versus benefits showed that on a small-scale livestock operation (i.e., an operation being affected by only 1 pack of coyotes), the cost of surgically sterilizing 1 coyote pack was recovered by the amount of losses averted within the same year. As alternative methods of delivering sterilants are developed (DeLiberto et al. 1998), sterilization may prove an efficient solution for changing the predatory behavior of coyotes on a larger scale. Sterilization could also be valuable in areas where lethal control is socially unacceptable (Mech et al. 1996) and where enhancement of fawn recruitment rates of native ungulates is a management objective.

\section{ACKNOWLEDGMENTS}

We thank T. Chaudhry, K. Duran, R. Farrar, L. Kellogg, L. Kemp, H. Smith, J. Stevenson, M. Wichrowski, P. Wilmot, and A. Woc-Colburn for field assistance; A. Barras, T. DeLiberto, T. Hall, A. Seglund, D. Zemlicka, and the staff at the Bear River Veterinary Clinic, Evanston, Wyoming, for assistance with surgical sterilization of covotes; $\mathrm{J}$. Anderson, G. Brennan, C. Meyer, and T. Milliken of Hawkins and Powers Aviation for helicopter flying and aerial net-gunning; R. Danvir and B. Hopkin of Deseret Land and Livestock for logistical assistance and access to the ranch; G. Gantz of InterWest Wildlife for aerial telemetry; and J. Bissonette, R. Danvir, M. Fall, F. Knowlton, D. Maehr, F. Provenza, and an anonymous reviewer for reviews of the manuscript. This study was funded and supported by the U.S. Department of Agriculture, National Wildlife Research Center, Logan Field Station. The Utah Agricultural Experiment Station at Utah State University provided funds for some supplies. Procedures for coyote capture, handling, immobilization, and surgical sterilization, and sheep husbandry procedures were reviewed and approved by Institutional and Animal Care and Use Committees at the National Wildlife Research Center (Q- -487 ) and Utah State University (\#845).

\section{LITERATURE CITED}

Andeit, W. F. 1987. Coyote predation. Pages 128-140 in M. Novak, J. A. Baker, M. E. Obbard, and B. Malloch, editors. Wild furbearer management and conservation in North America. Ontario Ministry of Natural Resources and the Ontario Trappers Association, Canada.

1996. Carnivores. Pages 133-155 in P. R. Krausman, editor. Rangeland wildlife. Society for Range Management, Denver, Colorado, USA.

BALSER, D. S. 1964. Management of predator populations with antifertility agents. Journal of Wildlife Management 28:352-358.

1965. Tranquilizer tabs for capturing wild carnivores. Journal of Wildlife Management 29:438-442.

BARRETT, M. W., J. W. Nol.AN, ANd L. D. RoY. 1982. Evaluation of a hand-held net-gun to capture large mammals. Wildlife Society Bulletin 10:108-114.

Boggess, E. K., F. R. Henderson, ANd C. E. Spaeth. 1980. Managing predator problems: practices and 
procedures for preventing and reducing livestock losses. Kansas State University Cooperative Extension Service Bulletin C-620, Manhattan, USA.

BOURNE, J., AND M. J. DORRANCE. 1982. A field test of lithium chloride aversion to reduce coyote predation on domestic sheep. Journal of Wildlife Management 46:235-239.

BROMLEY, C. 2000. Coyote sterilization as a method of reducing depredations on domestic lambs. Thesis, Utah State University, Logan, USA.

BubELA, T. M. 1999. Social effects of sterilizing freeranging red foxes in subalpine Australia. Dissertation, University of Sydney, Australia.

Carbyn, L. N., S. M. OOSEnbrug, and D. W. ANions. 1993. Wolves, bison and the dynamics related to the Peace-Athabasca Delta in Canada's Wood Buffalo National Park. Circumpolar Research Series 4, Canadian Circumpolar Institute, University of Alberta, Edmonton, Canada.

CoNNER, M. M., M. M. JAEger, T. J. WELleE, AND D. R. MCCullough. 1998. Effect of coyote removal on sheep depredation in northern California. Journal of Wildlife Management 62:690-699.

DeLiberto, T. J., E. M.Gese, F. F. KNOWLton, J. R. MASON, M. R. CONOVER, L. Miller, R. H. SCHMIDT, AND M. K. Holland. 1998. Fertility control in coyotes: is it a potential management tool? Vertebrate Pest Conference 18:144-149.

ELDER, W. H. 1964. Chemical inhibitors of ovulation in the pigeon. Journal of Wildlife Management 28:556-575.

Fritrs, S. H., AND L. D. MECH. 1981. Dynamics, movements, and feeding ecology of a newly protected wolf population in northwestern Minnesota. Wildlife Monographs 80.

FULLER, T. K. 1989. Population dynamics of wolves in north-central Minnesota. Wildlife Monographs 105.

GARROTT, R. A. 1995. Effective management of freeranging ungulate populations using contraception. Wildlife Society Bulletin 23:445-452.

Gee, C. K., R. S. Magleby, D. B. Nielson, and D. M. STEVENS. 1977. Factors in the decline of the western sheep industry. U.S. Department of Agriculture, Economic Research Service, Agricultural Economic Report 377.

Gese, E. M., D. E. ANDERSEN, AND O. J. Rongstad. 1990. Determining home-range size of resident coyotes from point and sequential locations. Journal of Wildlife Management 54:501-506.

- AND S. GROTHE. 1995. Analysis of coyote predation on deer and elk during winter in Yellowstone National Park, Wyoming. American Midland Naturalist $133: 36-43$.

, O. J. Rongstad, ANd W. R. Mytton. 1987. Manual and net-gun capture of coyotes from helicopters. Wildlife Society Bulletin 15:444-445.

GIER, H. T. 1968. Coyotes in Kansas. Kansas State College Agriculture Experiment Station Bulletin 393, Manhattan, USA.

Gober, D. R. 1979. Factors affecting domestic sheep losses to predators in Trans-Pecos, Texas. Dissertation, Texas A\&M University, College Station, USA.

GUTHERY, F. S. 1977. Efficacy and ecological effect of predator control in south Texas. Dissertation, Colorado State University, Fort Collins, USA.

HaIGHT, R. G., AND L. D. MECH. 1997. Computer simu- lation of vasectomy for wolf control. Journal of Wildlife Management 61:1023-1031.

Hamlin, K. L., S. J. Riley, D. Pyrah, A. R. DoOd, AND R. J. MACKIE. 1984. Relationships among mule deer fawn mortality, coyotes and alternate prey species during summer. Journal of Wildlife Management 48:489-499.

HARRINGTON, F. H., AND L. D. MECH. 1982. An analysis of howling response parameters useful for wolf pack censusing. Journal of Wildlife Management 46:686-693.

HARRISON, D. J., AND J. A. HARRISON. 1984. Foods of adult Maine coyotes and their known-aged pups. Journal of Wildlife Management 48:922-926.

HEISEY, D. M., AND T. K. FulLER. 1985. Evaluation of survival and cause-specific mortality rates using telemetry data. Journal of Wildlife Management 49:668-674.

HoffmaN, S. W. 1979. Coyote-prey relationships in Curlew Valley during a period of low jackrabbit density. Thesis, Utah State University, Logan, USA.

KAUFFELD, J. D. 1977. Availability of natural prey and its relationship to coyote predation on domestic sheep. Thesis, University of Nevada, Reno, USA.

KIE, J. G., J. A. BALDWIN, AND C. J. Evars. 1996. Calhome: a program for estimating animal home ranges. Wildlife Society Bulletin 24:342-344.

KirkPatrick, J. F., I. K. M. LU, AND J. W. TURNer, JR. 1990. Remotely-delivered immunocontraception in feral horses. Wildlife Society Bulletin 18:326-330.

KLEBENOW, D. A., AND K. M. MCADOo. 1976. Predation on domestic sheep in northeastern Nevada. Journal of Range Management 29:96-100.

Knowlton, F. F., E. M. Gese, AND M. M. JAEger. 1999. Coyote depredation control: an interface between biology and management. Journal of Range Management 52:398-412.

LEHNER, P. N. 1987. Repellents and conditioned avoidance. Pages 56-61 in J. S. Green, editor. Protecting livestock from coyotes. U.S. Department of Agriculture, Agricultural Research Service. U.S. Sheep Experiment Station, Dubois, Idaho, USA.

LINHART, S. B., AND F. F. KNOWLTON. 1967. Determining age of coyotes by tooth cementum layers. Journal of Wildlife Management 31:362-365.

Matschke, G. H. 1977. Microencapsulated diethylstilbestrol as an oral contraceptive in the white-tailed deer. Journal of Wildlife Management 41:87-91.

MCAdOO, J. K. 1975. Predation on domestic sheep in northwestern Nevada. Thesis, University of Nevada, Reno, USA.

MECH, L. D. 1966. The wolves of Isle Royale. U.S. National Park Service, Fauna Series 7:1-210.

1970. The wolf: the ecology and behavior of an endangered species. Natural History Press, Garden City, New York, USA.

1983. Handbook of animal radio tracking. University of Minnesota Press, Minneapolis, USA.

, S. H. FritTS, AND M. E. Nelson. 1996. Wolf management in the 21 st century, from public input to sterilization. Journal of Wildlife Research 1:195-198. -, , AND W. J. PAUl. 1988. Relationship between winter severity and wolf depredations on domestic animals in Minnesota. Wildlife Society Bulletin 16:269-272.

MEssier, F. 1985. Social organization, spatial distribution and population density of wolves in relation to moose density. Canadian Journal of Zoology 63:1068-1077. 
Millar, S. E., S. M. Chamow, A. W. Baur, C. Oliver, F. ROBEY, AND J. DEAN. 1989. Vaccination with a synthetic zona pellucida peptide produces long-term contraception in female mice. Science 246:935-938.

Oftedal, O. T., AND J. L. Gittleman. 1989. Patterns of energy output during reproduction in carnivores. Pages 355-378 in J. L. Gittleman, editor. Carnivore behavior, ecology and evolution. Comstock Publishing Associates, Cornell University Press, Ithaca, New York, USA.

PeARson, E. W. 1986. A literature review of livestock losses to predators in western U.S. U.S. Fish and Wildlife Service Final Report, Denver, Colorado, USA.

PeCH, R., G. M. HoOd, J. McIlroy, AND G. SAUnders. 1997. Can foxes be controlled by reducing their fertility? Reproduction, Fertility and Development 9:41-50.

PETERSON, R. O. 1977. Wolf ecology and prey relationships on Isle Royale. U.S. National Park Service Scientific Monograph Series 11:1-210.

PlotKa, E. D., AND U. S. SeAL. 1989. Fertility control in female white-tailed deer. Journal of Wildlife Diseases 25:643-646.

ReIter, D. K., M. W. Brunson, AND R. H. SChMidT. 1999. Public attitudes toward wildlife damage management and policy. Wildlife Society Bulletin 27:746-758.

RowLEY, I. 1970. Lamb predation in Australia: incidence, predisposition conditions, and the identification of wounds. CSIRO Wildlife Research 15:79-123.

ROYAMA, T. 1970. Factors governing the hunting behavior and selection of food by the great tit (Parus major). Journal of Animal Ecology 39:619-669.

SACks, B. N., M. M. Jaeger, J. C. C. NeAle, AND D. R. MCCullough. 1999. Territoriality and breeding status of coyotes relative to sheep predation. Journal of Wildlife Management 63:593-605.

SAHR, D. P., AND F. F. KNOWLTON. 2000. Evaluation of tranquilizer trap devices (TTD's) for foothold traps used to capture gray wolves. Wildlife Society Bulletin 28:597-605.

SAunders, G., AND J. McIlroy. 1996. The effect of imposed sterility on the survival, fecundity, territoriality and social structure of foxes. Abstract, 4th International Conference on Fertility Control for Wildlife Management, Great Keppel Island, Queensland, Australia.

Shivik, J. A., M. M. JAEger, AND R. H. BarretT. 1996. Coyote movements in relation to the spatial distribution of sheep. Journal of Wildlife Management $60: 422-430$.
SimPSON, L. L. 1995. Sheep and lamb death loss. U.S. Department of Agriculture, National Agricultural Statistics Service, Staff Report LDP 95-01, Washington, D.C., USA.

Smrth, G. W., AND N. C. NyDEGGer. 1985. A spotlight, line transect method for surveying jack rabbits. Journal of Wildlife Management 49:699-702.

Stellfug, J. N., N. L. Gates, AND R. G. SASSER. 1978. Reproductive inhibitors for coyote population control: development and current status. Vertebrate Pest Conference 8:185-189.

Thurber, J. M., AND R. O. Peterson. 1993. Effects of population density and pack size on the foraging ecology of gray wolves. Journal of Mammalogy 74:879-889.

TIGNER, J. R., AND G. E. LARSON. 1977. Sheep losses on selected ranches in southern Wyoming. Journal of Range Management 30:244-252.

TILL, J. A. 1982. Efficacy of denning in alleviating coyote depredations upon domestic sheep. Thesis, Utah State University, Logan, USA.

— AND F. F. KNowLTON. 1983. Efficacy of denning in alleviating coyote depredations upon domestic sheep. Journal of Wildlife Management 47:1018-1025.

U.S. DEPARTMENT OF AgRICULTURE. 1998. Utah sheep report. National Agricultural Statistics Service, Agricultural Statistics Board, Washington, D.C., LSA.

Wade, D. A., ANd J. E. Bowns. 1985. Procedures for evaluating predation on livestock and wildlife. Texas Agricultural Experiment Station, Texas A\&M University Bulletin B-1429, College Station, USA.

WAGNer K. K., AND M. R. Conover. 1999. Effect of preventive coyote hunting on sheep losses to coyote predation. Journal of Wildlife Management 63:606-612.

White, G. C., AND R. A. GARROTt. 1990. Analysis of wildlife radio-tracking data. Academic Press, New York, USA.

WORTON, B. J. 1989. Kernel methods for estimating the utilization distribution of home range studies. Ecology 70:164-168.

ZEMLICKA, D. E. 1995. Seasonal variation in the behavior of sterile and nonsterile coyotes. Thesis, Utah State University, Logan, USA.

Received 17 July 2000.

Accepted 1 February 2001.

Associate Editor: Maehr. 